\title{
Predicting favourable areas for landsliding through GIS modelling in Aparados da Serra (Brazil)
}

\author{
A. J. Strieder ${ }^{1}$, S. A. Buffon ${ }^{1}$, T. F. P. de Quadros ${ }^{2}$ \\ \& H. R. Oliveira ${ }^{3}$ \\ ${ }^{1}$ Lab. Modelagem Geológica e Ambiental, MODELAGE-UFRGS, Brazil \\ ${ }^{2}$ Fund. Estadual de Proteção Ambiental, FEPAM - SEMA-RS, Brazil \\ ${ }^{3}$ Transportadora Gasoduto Bolivia-Brasil S.A., TBG-Sul
}

\begin{abstract}
This paper presents the results of GIS modelling for predicting areas where natural landslides can occur in the Aparados da Serra region (Southern Brazil). The scarp is mainly developed upon basalts and dacites (Serra Geral Fm.) and sandstones (Botucatu Fm.) of the Paraná Basin. The $1000 \mathrm{~m}$ high scarp has been geomorphologically evolving since the break-up of the Gondwana Supercontinent and the opening of the South Atlantic Ocean. Geologic, geomorphologic and geotechnical mapping were conducted in order to acquire field data and to define a conceptual geomorphologic-geotechnical model for GIS data modelling. These mappings were aided with ASTER image processing and aerial photograph analysis. ASTER images do permit a high resolution and accurate DEM. The prediction of areas able to develop natural landslides along the scarp was based upon Factor of Safety (FS) algorithms. The GIS modelling results for Aparados da Serra region were grouped into four categories. The areas with the lowermost FS number were defined as highly susceptible to developing natural landslides. Field investigations upon some existing landslide structures in the region do confirm such predictions. However, large scale FS determination through GIS modelling in order to predict susceptible areas for landslides must be interpreted in a relative manner. FS modelling can, then, be applied to landslide susceptibility mapping in areas of poor historical records, since supported by adequate geological and geotechnical investigations.

Keywords: landslides, susceptibility maps, GIS modelling, factor of safety.
\end{abstract}




\section{Introduction}

Landslides are a natural phenomenon which include a wide variety of material, such as debris, soils, rocks, organic matter, and constructions, moving downslope [1]. Landslides describe many types of down-slope mass movement, ranging from rapidly moving catastrophic rock avalanches and debris flows, to slowly moving earth slides.

Landslides concerned here relate to slow rotational and translational slides of debris and soils [2]. The gravity is the main driving force for these slides, but a number of factors can influence them. The increase in water content, for example, contributes to loading of the debris and soil materials in the slope. In the same way, the shear strength of the slope material is decreased while the pore water pressure is increased. This seems to be the second main driving force for landslides in tropical countries, such as Aparados da Serra region in Southern Brazil.

Landslide susceptibility maps are produced by a number of methods by means of GIS. Quantitative methods may include inventory, slope angle, terrain aspect, geology, vegetation, land use maps overlaid through the named landslide susceptibility matrix technique [3]. Multivariate analysis of factors controlling landslides are also developed [4]. GIS development enhanced landslide susceptibility analysis in different ways (e.g. [5,6,7]). It seems that an inventory of historical data is a key factor in landslide susceptibility map construction. However, how can a landslide susceptibility map be assessed in areas displaying poor landslides records?

This paper aims to present a landslide susceptibility map for Aparados da Serra area (Southern Brazil, fig. 1) based on a rational deterministic approach [8] through GIS modelling. The prediction of areas able to develop natural landslides along the Aparados da Serra scarp was based upon Factor of Safety (FS) algorithms. The factor of safety (FS) was determined for high resolution areas $(15 \mathrm{~m})$ according the discussion by $\mathrm{Wu}$ and Abdel-Latif [9]. The results were tested looking at some existing, shallow landslides at Aparados da Serra scarp.

\section{Geological and geotechnical investigations: a landslide model for Aparados da Serra (Southern Brazil)}

The Aparados da Serra region (Southern Brazil) shows a $1000 \mathrm{~m}$ high scarp developed since the break-up of the Gondwana Supercontinent and the opening of the South Atlantic Ocean. It mainly exposes Botucatu Fm. (sandstones) at the base, and basalts and dacites of Serra Geral Fm. up-ward. The base of scarps has thick Tertiary talus deposits, cemented by iron oxides and hydroxides.

ASTER image processing through AsterDTM tool of ENVI software (RSI) do permit a high resolution $(15 \mathrm{~m})$ and accurate digital terrain model. The coordinate system was set to SAD69/96. ASTER and LANDSAT images processing, DTM, aerial photographs analysis and fieldworks were performed to 
produce the geologic, geomorphologic and geotechnical maps. These data were all introduced in ArcGIS software (ESRI) for additional modeling.

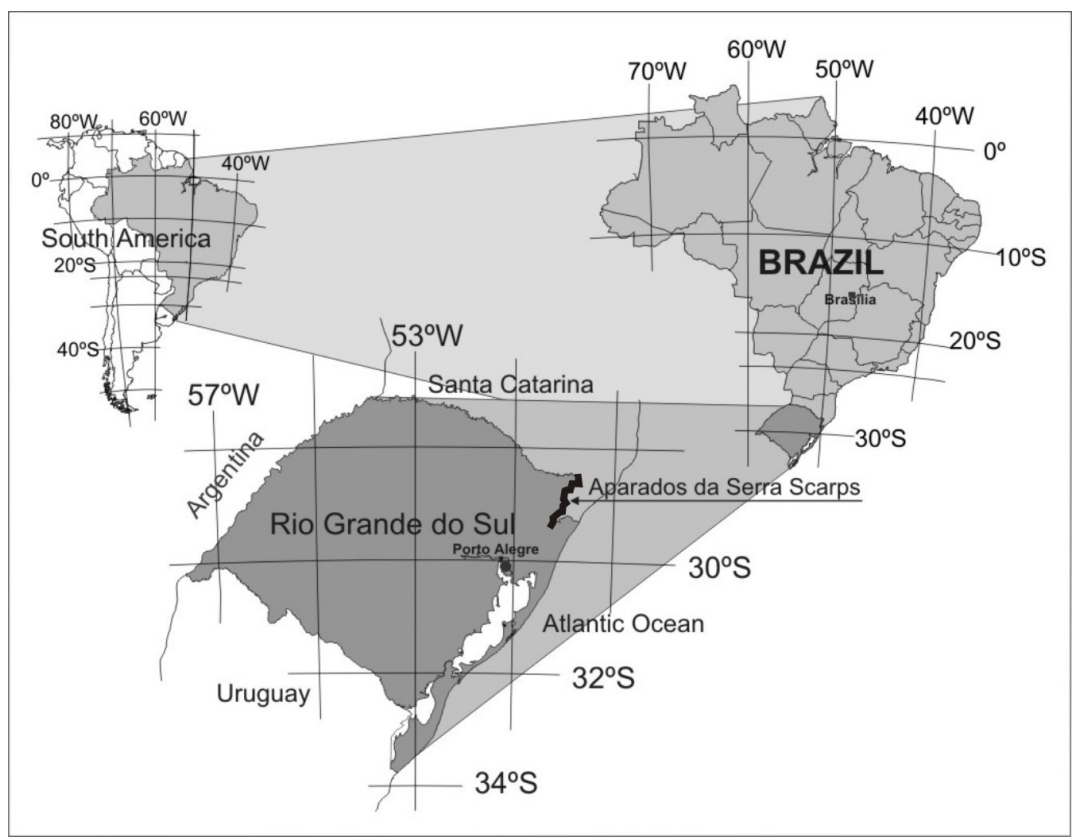

Figure 1: Regional map locating Aparados da Serra region, Southern Brazil.

Geological mapping could distinguish 29 volcanic flows composing the Serra Geral Fm. 15 of these flows are made of basic volcanic rocks (basalts), while 14 of them are acid volcanic rocks (dacites). The limit of basic and acid volcanic rocks is set at $800 \mathrm{~m}$ of altitude. The lower contact of Serra Geral volcanic rocks is close to $245 \mathrm{~m}$ of altitude.

Geomorphologic mapping defined a step-platform structure for Aparados da Serra scarp (Fig. 2). Under these structural conditions, recent weathering and mass wasting processes accumulated debris and soils as triangular prisms of colluviums over the platforms. The soils are mainly composed of clays, and some of them show latteritic features.

Geotechnical and geomorphologic mapping recognized a vertical differentiation for colluviums prisms. In the higher scarps ( $>800 \mathrm{~m}$ of altitude), the step height is close to or greater than platform length (Fig. 2). On the other hand, in the middle and lower part of the Aparados da Serra scarp $(<800 \mathrm{~m}$ of altitude), the platform length is much greater than step height. It was also noticed that soils have low thickness $(<5 \mathrm{~m})$ in the upper scarp, while they show up to $30-40 \mathrm{~m}$ in some places of the lower scarp. These differentiations explain why some block falls are reported in the upper scarp, and why some shallow, translational slides are reported in the lower scarp. 
The shallow (1-3 $\mathrm{m}$ depth), translational slides in the Aparados da Serra region (Southern, Brazil) shows clear elliptical shapes. They wide vary from 8 to $25 \mathrm{~m}$, and the length is greater than 25-30 m. Laboratory geomechanic essays of colluviums in the Aparados da Serra region were done by Silveira [10] (Table 1).

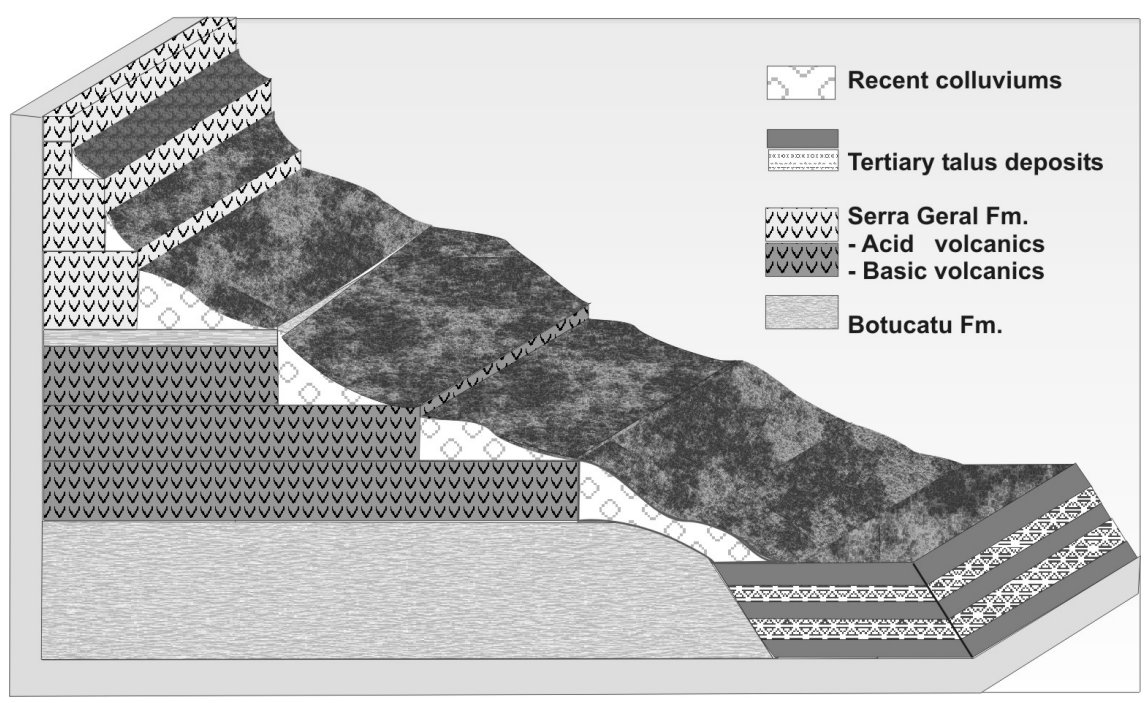

Figure 2: Geologic-geomorphologic structure of the Aparados da Serra region (Southern Brazil).

Table 1: Geomechanic properties of colluviums in the Aparados da Serra region (Southern Brazil).

\begin{tabular}{|l|l|l|l|}
\hline Geomechanic parameters & Mean & Minimum & Maximum \\
\hline$\rho w$ (water density) & 9,806 & 9,806 & 9,806 \\
\hline$\rho s$ (natural soil density) & 18 & 15,5 & 20,4 \\
\hline$\rho w / \rho s$ ratio & 0,544778 & 0,632645 & 0,480686 \\
\hline$\rho t$ (saturated soil density) & 28,15 & 27,7 & 28,6 \\
\hline$\rho$ (dry soil density) & 11,7 & 10,5 & 12,9 \\
\hline$\Phi$ peak (peak shear strength) & 29,5 & 28 & 31 \\
\hline$\Phi$ residual (residual shear strength) & 16 & 10 & 18 \\
\hline$\beta$ (slope) & 20 & 2 & 70 \\
\hline tanФpeak/tan $\beta \quad$ ratio & 1,554448 & 15,22617 & 0,218695 \\
\hline tanФres/tan $\beta$ ratio & 0,787826 & 5,049344 & 0,118261 \\
\hline Triaxial cohesion & 18 & 12,5 & 25 \\
\hline Undeformed direct shear cohesion & 27 & 25 & 28 \\
\hline
\end{tabular}




\section{Predicting favourable areas for landslide through FS}

Predicting favourable areas for landslides through FS determination in GIS environment requires an evaluation on existing landslide dimensions. In this way, the reported landslide in the Aparados da Serra region covers 1-2 pixels in wide and 3-5 pixels in length. The dimensions of reported landslides enable classification procedure through filtering in ENVI software.

The main variables to be considered in mathematical modelling are:

- W (mean wide of landslide structures);

- $\quad$ L (mean length of landslide structures);

- D (colluviums thickness);

- $\quad \mathrm{H}$ (water table height);

- $\quad \phi$ (effective shear strength),

- $\beta$ (slope).

These characteristics enable some simplification in FS computing through GIS modelling. Mean $\mathrm{W}$ and $\mathrm{L}$ for reported landslide structures are greater than pixel resolution $(15 \times 15 \mathrm{~m})$. Colluviums thickness can be computed from DTM pixel and lower volcanic flow platform. The computed colluviums thickness map shows lateral and longitudinal slope variations. The deterministic FS model can, in this way, consider that forces acting parallel to slope are in equilibrium and that the slope is infinite. These conditions can be applied chiefly to middle and lower scarps of the Aparados da Serra region.

The FS determination can take the equation presented by Haneberg [8]:

$$
\mathrm{FS}=\{1-[(\rho \mathrm{w} / \rho \mathrm{s}) .(\mathrm{H} / \mathrm{D})]\} .(\tan \phi / \tan \beta)
$$

However, equation 1 applies to low cohesion, unconsolidated materials. A more realistic FS determination must then consider cohesion of colluviums deposited over the volcanic basement. The equation presented by $\mathrm{Wu}$ and Abdel-Latif [9] takes cohesion into account and was developed for planar failure and infinite slope:

$$
\begin{aligned}
\mathrm{FSp}= & \left\{\mathrm{cf}+\mathrm{c}^{\prime}+[\rho(\mathrm{D}-\mathrm{H})+(\rho \mathrm{t}-\rho \mathrm{w}) \mathrm{H}] \cos ^{2} \beta \tan \phi\right\} \\
& /\{[\rho(\mathrm{D}-\mathrm{H})+\rho \mathrm{tH}] \sin \beta \cos \beta\}
\end{aligned}
$$

where c' is cohesion and cf is cohesion increase for forested areas.

The FS is clearly dependent on variations of physical properties. But, water table is known to influence slope failure. The water table is not parallel to groundsurface and varies according thickness, composition and permeability of soils. It is also dependent on precipitation: it is well known that slope failure occur during on immediately after raining periods, when water table is high enough to decrease colluviums shear strength. Taking into account that water table (piezometers) close to a monitored landslide in Aparados da Serra (Southern Brazil) is 1-2 m below the groundsurface during dry periods. Then, it is possible to consider $\mathrm{H}=\mathrm{D}$ (conservative approach) and determine FS for extreme situations.

Cohesion increase due to vegetation cover was not considered in this FS determination. The dense Atlantic forest cover surely contributes to cohesion and to FS value. The influence of Atlantic forest in cohesion increase for colluviums is being investigated. It is interesting to note, in this respect, that shallow 
landslides reported in Aparados da Serra region occur in deforested areas. Then, to partially overcome this uncertainty, it was taken into account undeformed direct shear cohesion in FS determination.

\section{Landslide susceptibility map for Aparados da Serra region}

The FS is the ratio between resisting to driving forces acting in slope failure. It is usually said that FS $>1$ represents stable conditions, while FS $<1$ represents unstable conditions. A FS $\sim 1.25$ or somewhat higher is generally accepted for slope stability. However, this determination is valid for a specific slope, where all the geomechanic parameters are known, controlled and modeled.

Table 2 shows that FS is very sensitive to slope angle and colluviums thickness. The colluviums in the Aparados da Serra region show small variations in cohesion, shear strength, and densities when regional analysis is performed. However, FS rapidly decrease to values lower than 1 when slope angle goes to $25(\mathrm{D}=5)$, and to $17(\mathrm{D}=10)$. It is also realized that FS decreased $1 / 3$ as colluviums thickness increased by 2 .

Table 2: Sensitivity analysis of Aparados da Serra colluviums considering FS equation presented by $\mathrm{Wu}$ and Abdel-Latif [9]. FS was calculated for different slope angles and two colluviums thickness (D). Water table was fixed to be $1 \mathrm{~m}$ below the groundsurface.

\begin{tabular}{|r|l|l|}
\hline & $\mathrm{D}=5$ & $\mathrm{D}=10$ \\
\hline$\beta$ & $\mathrm{H}=4$ & $\mathrm{H}=9$ \\
\hline & FSp5 & FSp10 \\
\hline 2 & 12,02876 & 8,528288 \\
\hline 4 & 6,018449 & 4,264291 \\
\hline 6 & 4,016854 & 2,843039 \\
\hline 8 & 3,01748 & 2,132492 \\
\hline 10 & 2,419042 & 1,706247 \\
\hline 12 & 2,021122 & 1,422175 \\
\hline 16 & 1,526263 & 1,067379 \\
\hline 20 & 1,232421 & 0,854974 \\
\hline 24 & 1,039572 & 0,713977 \\
\hline 28 & 0,905004 & 0,614038 \\
\hline 32 & 0,807534 & 0,540058 \\
\hline 40 & 0,682551 & 0,44025 \\
\hline 50 & 0,611113 & 0,371193 \\
\hline 60 & 0,618595 & 0,348311 \\
\hline
\end{tabular}

The determination of FS in large regions using a GIS environment must overcome large scale parameters variability. This introduces uncertainties in GIS modelling. The FS values determined in GIS environment varies from 0.2 to up 
to 200. Taking into account the sensibility of FS equation (2) for geomechanic physical parameters, the predicted map of FS was computed for two different cases: i) residual shear strength $\left(\phi=16^{\circ}\right)$, that is the worst condition attained during and after raining periods, and ii) peak shear strength $\left(\phi=29^{\circ}\right)$. The predicted FS maps are presented in figure $3 \mathrm{~A}$ and $3 \mathrm{~B}$, respectively. Based on the locations of some recorded shallow landslides in the Aparados da Serra region (Southern Brazil), it was possible to define five classes of susceptibility based in FS values (Table 3).
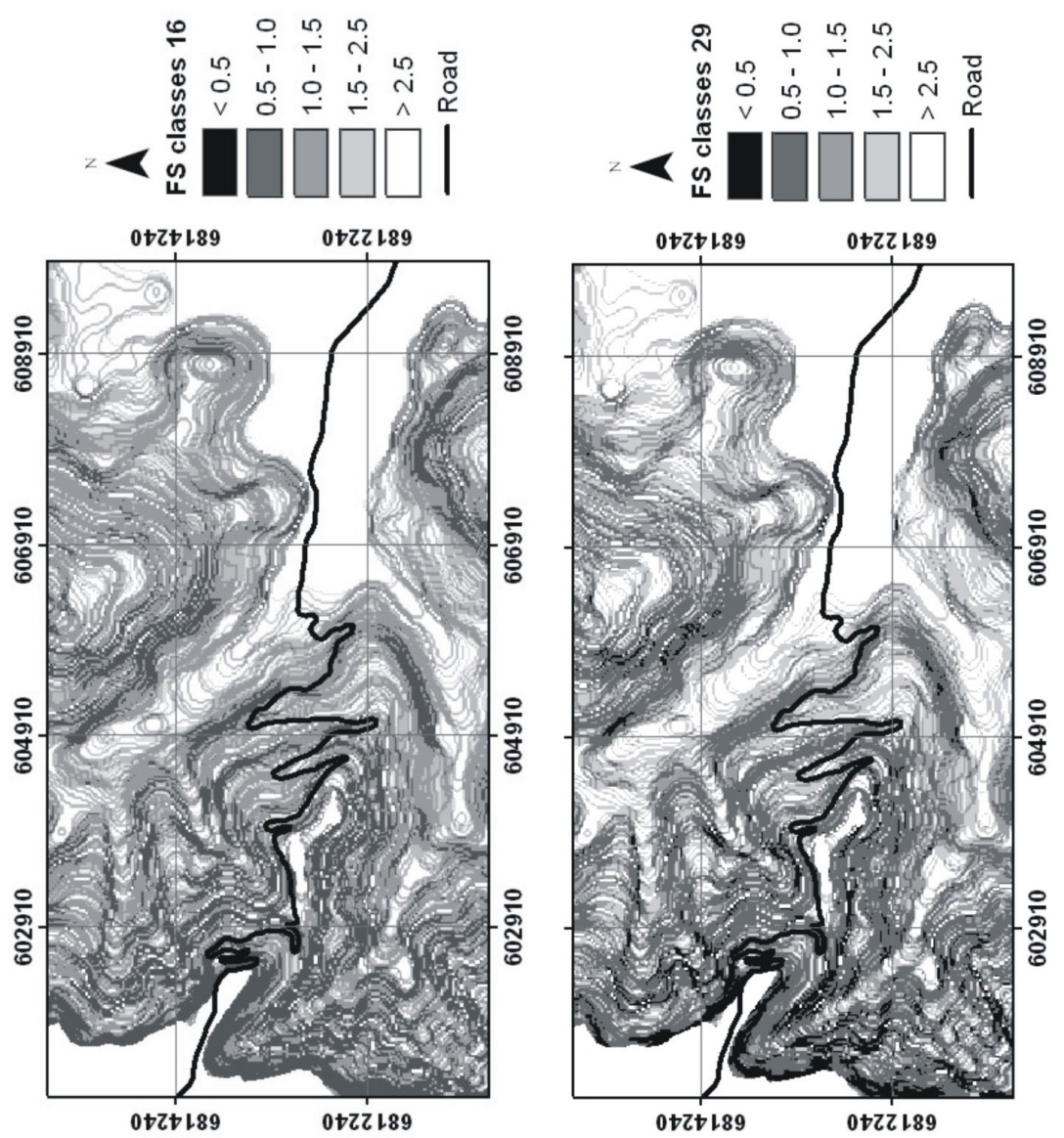

Figure 3: Landslide susceptibility map for Aparados da Serra region (Southern Brazil), based in FS equation presented by Wu \& Abdel-Latif [9]. A) Predicted FS classes using residual shear strength $\left(\phi=16^{\circ}\right)$. B) Predicted FS classes using peak shear strength $\left(\phi=29^{\circ}\right)$. 
Table 3: Susceptibility classes for landslides in the Aparados da Serra region (Southern Brazil), based in FS equation presented by Wu \& AbdelLatif [9]. Susceptibility classes defined for residual shear strength $(\phi$ $\left.=16^{\circ}\right)$ and for peak shear strength $\left(\phi=29^{\circ}\right)$.

\begin{tabular}{|l|c|c|c|}
\hline \multicolumn{1}{|c|}{ Predicted FS } & $\begin{array}{c}\text { Susceptibility } \\
\text { class }\end{array}$ & \multicolumn{2}{c|}{ FSp } \\
\hline Areas highly favourable for landslides & $\mathbf{1}$ & & $<0.5$ \\
\hline Areas favourable for landslides & $\mathbf{2}$ & $>0.5$ & $<1.0$ \\
\hline Areas that can develop landslides & $\mathbf{3}$ & $>1.0$ & $<1.5$ \\
\hline Areas not favourable for landslides & $\mathbf{4}$ & $>1.5$ & $<2.5$ \\
\hline Stable areas under natural conditions & $\mathbf{5}$ & $>2.5$ & \\
\hline
\end{tabular}

\section{Discussion}

The Factor of Safety determination using GIS modelling can be a useful technique for assessing landslide susceptibility map in areas of poor historical records on hillslopes of tropical regions, such as Aparados da Serra (Southern Brazil). The methods based on intense data records seek on statistical and multivariate capabilities for an adequate susceptibility map assess in Aparados da Serra region. In this way, careful geological, geotechnical and geomorphologic investigations in existing records were applied to assess the main causes of shallow, translational and rotational landslides in Aparados da Serra region. The geological and geotechnical model for Aparados da Serra region, the accurate and high resolution DTM $(15 \times 15 \mathrm{~m})$, and the GIS capabilities do enable FS determination.

The FS determination, however, introduces uncertainties in GIS modelling due to spatial variability of parameters. The value determined for each cell (15x15 m pixel) must be evaluated in a relative way. Then, a careful examination of existing records surely helps on establishing the limits between different classes. It is to be kept in mind that absolute FS value is an important parameter for construction decision in a given, specific investigation site, where a large number of geotechnical soil properties are well controlled.

Landslide susceptibility map derived form FS determination in Aparados da Serra (Southern Brazil) helps, in this way, in showing "where" the areas more favourable to develop translational and rotational slides are. Ongoing investigation on Atlantic forest contribution on soils and colluviums cohesion can put some clues on questions regarding "when" and "how big" these landslides can be.

\section{Acknowledgements}

The authors want to thank FINEP, PETROBRAS and TBG (Proc. No. 0682/01) for research funds that supported this investigation. 


\section{References}

[1] Cruden, D.M., A simple definition of a landslide, Bull. IAEG, 43, pp. 2729, 1991.

[2] Cruden, D.M. \& Varnes, D.J., Landslide Types and Processes. Landslides Investigation and Mitigation, A.K. Turner \& R.L. Shuster Eds.. Transportation Research Board, Special Report 247, Washington DC, p.36-75, 1996.

[3] DeGraff, J.V. \& Romesburg, H.C., Regional landslide-susceptibility assessment for wildland management: a matrix approach. Thresholds in Geomorphology, D.R. Coates \& J. Vitek Eds., George Alien \& Unwin Publ., pp. 401-414, 1980.

[4] Carrara, A., Multivariate models for landslide hazard evaluation, Mathematical Geology, 15(3), 403-426 pp., 1983

[5] Carrara, A., Cardinali, M., Guzzetti, F., \& Reichenbach, P., GIS technology in mapping landslide hazard, Geographical Information Systems in Assessing Natural Hazards, A. Carrara \& F. Guzzetti Eds, Kluwer Academic Publishers, pp. 135-175, 1995.

[6] Santacana, N., Baeza, B., Corominas, J., Paz, A. \& Marturia, J., A GISbased multivariate statistical analysis for shallow landslide susceptibility mapping in La Pobla de Lillet area (Eastern Pyrenees, Spain), Natural Hazards 30: 281-295, 2003.

[7] Tangestani, M.H., Landslide susceptibility mapping using the fuzzy gamma approach in a GIS, Kakan catchment area, southwest Iran, Australian Journal of Earth Sciences, 51(3), pp. 439-450, 2004.

[8] Haneberg, W.C., Deterministic and probabilistic approaches to geologic harzad assessment, Environmental \& Engineering Geoscience, 6(3), pp. 209-226, 2000.

[9] Wu, T.H. \& Abdel-Latif, M.A., Prediction and mapping of landslide hazard, Can. Geotech. J., 37, pp. 781-795, 2000.

[10] Silveira, R.M., Propriedades geotécnicas dos solos coluvionares do gasoduto Bolívia-Brasil em Timbé do Sul (SC), Dissertação de Mestrado em Engenharia Civil, Escola de Engenharia/UFRGS, Porto Alegre, 131 pp, 2003 